\title{
VSEŽIVLJENJSKO UČENJE ZA AKTIVNO DEMOKRACIJO Razširitev političnega diskurza
}

Ian Martin

univerza

$v$ Edinburghu
K no populacijo v krizi - postane državljanstvo sredstvo za pogovor in razmišljanje o tem.

Eden od načinov, kako ustvariti razmere, v katerih bo vseživljenjsko učenje gibalo aktivnega državljanstva, je, da razširite $v$ diskurz političnega programa (Martin, 1999). Diskurz po Edwardsu in Usherju (1994) »določa, kaj se lahko reče, kar pa v bistvu izhaja iz tega, kaj se ne sme reči, kaj je nepomembno, kaj je treba zamolčati in kaj docela pozabiti«. Njegov pomen je v tem, da skušamo z njim razrahljati diskurzivne "plašnice « in z njim razširimo svoje vidno polje. Kaj pomeni pravzaprav razširiti diskurz? Za lažje razumevanje bom predstavil delo skupine, katere član sem bil tudi sam. Ukvarjala se je $\mathrm{z}$ družino, skupnostjo ter učenjem za državljanstvo. Skupina je bila ena od štirih, ki je bila izbrana za svetovanje enemu od političnih organov britanske vlade, imenovala pa se je Nacionalna svetovalna skupina za nadaljevalno izobraževanje in vseživljenjsko učenje. Rezultat našega dela je bila publikacija - Fryerjevo poročilo Učenje za enaindvajseto stoletje (Fryer, 1997).

Zamisel je bila preprosta: izbrati sprejemljive izraze v besednjaku političnega dogajanja in njihov pomen razširiti navzven. $S$ tem bi zajeli nekatere najbolj pereče dejavnike $\mathrm{v}$ izobraževanju za vključevanje $\mathrm{v}$ družbene dejavnosti, demokratičnega sodelovanja in aktivnega državljanstva. Ključne besede, ki smo jih izbrali za to obdelavo, so bile: vseživljenjsko učenje, državljanstvo, dostopnost, upravičenost, partnerstvo in razvijanje sposobnosti.

\section{- Vseživljenjsko učenje}

Vseživljenjsko učenje je proces, ki zajema individualno in skupinsko učenje. Učeča se družba se lahko razvije le, če resnično kulturo učenja gojijo družine in skupnosti. Zato mora biti vseživljenjsko učenje zakoreninjeno v življenju $v$ skupnostih in se mora neposredno ter ustvarjalno po-
Vseživljenjsko učenje je ključno gibalo demokratičnih ciljev družbe. vezovati $\mathrm{z}$ interesi, željami in potrebami navadnega človeka. Osredotočenost na življenje v skupnostih preusmeri osredotočenost interesov na družbene tokove $\mathrm{v}$ civilni družbi, stran od institucionalnih državnih struktur.

\section{- Učenje za državljanstvo}

Državljanstvo razumemo kot dejavno, vse zajemajočo kategorijo, ki prevzema pravice in dolžnosti. Ljudje se lahko naučijo, kako postati dejavni, ozaveščeni in kritični državljani. $\mathrm{V}$ demokratični in pluralistični družbi mora biti vseživljenjsko učenje opredeljeno tako, da spoštuje raznolikost in posebnosti različnih skupnosti ter hkrati goji solidarnost in državljanjsko kulturo $\mathrm{v}$ širši skupnosti. 


\section{- Demokratično delovanje}

Za vse državljane bi moralo veljati, da se od njih pričakuje zavezanost demokratičnemu družbenemu delovanju in usposobljenost zanj. Demokratična država mora temeljiti na demokratičnem načinu življenja. Končno je demokracija odvisna od zdravja in vitalnosti družin, skupnosti in prostovoljskih združenj v civilni družbi.

\section{Demokratičnost pomeni tudi to, da je izobraževanje dostopno usem državljanom.}

ki trenutno vladajo med različnimi finanserji v celotnem izobraževalnem sistemu. Te povezave je treba usmerjati tako, da bodo zagotovile prave oblike participacije, prerazporejanja in pooblastil, predvsem $\mathrm{v}$ korist zapostavljenih in izključenih skupin. To pomembno vpliva na institucionalne strukture, odnose $\mathrm{v}$ stroki, politiko in postopke financiranja.

\section{- Izboljševanje sposobnosti skupnosti}

Če želimo izboljšati raven usposobljenosti v skupnosti, je nujno, da se izognemo zelo preprostemu razlikovanju med izobraževanjem in usposabljanjem, pravimi vrednota$\mathrm{mi}$ in uporabnimi cilji ter individualno in kolektivno razsežnostjo učenja. Dolgoročno lahko človeški kapital učinkovito služi gospodarstvu le, če se v skupnosti hkrati sistematično razvijata družbeni in kulturni kapital na lokalni, regionalni, nacionalni in internacionalni ravni.

Tako širjenje diskurza je eden od načinov oblikovanja programov družbenega izobraževanja (Barrat Brown, 1998), ki nam lahko pomaga, da se bolj strateško usmerimo v naših vizijah in postanemo hkrati bolj vizionarski $\mathrm{v}$ naših strategijah. In navsezadnje, kot meni Jacques Delors (1996), je smisel

Pojavlja se potreba, da ponovino pretehtamo in razsinimo pojem vsezivljenjskega izobraževanja. To se nona prilagajali sprenenbam in naravi dela, vpeliati nenehen proces oblikovanja celostin cloveskih birï - tako znanja in sposobnosti ter veeplanja kriticnega misljena in razvijanja sposobnosti za delovanje. Tuludi bi morali nauciti, da bi se zavedali sebe in svojega okolia, in ih spodbuati, da odigrajo svojo druźbeno vlogo pri delu in y skupnosti.

\section{- Partnerstvo za skupno moč}

S spodbujanjem partnerskih sporazumov pri ustvarjanju možnosti za učenje se je treba obrniti na neenakomerno razporejene moči,

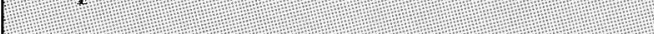


vseživljenjskega učenja $\mathrm{v}$ učeči se družbi predvsem v tem, da razvija človekovo delovanje in potenciale $v$ najširšem pogledu in čim celoviteje.

To pomeni, da moramo najprej doumeti, da je največja ovira, ki preprečuje uresničevanje vizije »kulture vseživljenjskega učenja za vse« (Fryer, 1997), trajna socialna, izobraževalna in materialna neenakost - in se $\mathrm{z}$ njo spoprijeti. Ta ustaljena neenakost dejansko ustvarja socialno izključenost in zavira aktivno državljanstvo.

Da bi lahko ustvarili povezavo med vseživljenjskim učenjem in aktivnim državljanstvom, moramo ponovno in dokončno doumeti, da se ljudje učijo postati aktivni državljani v demokratični družbi - in še več, spoznati, da so njihove sposobnosti za učenje in spreminjanje že od nekdaj ključni vir za sprejemanje demokracije kot načina življenja.

Državljanstvo je dinamièni, zgodovinski proces družbene transformacije, v kateri se počasi ustvarja in uresničuje zahreva po vecjih socialnih pravicah in enakopravnejsien druzbenem redu /Carr in Hartnet, 1996).

To je nenehen - pravzaprav vseživljenjski proces, ki se mora začeti $z$ vse obsegajočo vizijo o tem, kakšno naj bi bilo učenje in življenje v demokraciji. To pa zahteva preoblikovanje naše miselnosti o učenju, vseživljenjskem učenju in učenju za življenje - pa tudi o priložnostih, ki jih za to ustvarimo. Raymond Williams, pionir na področju izobraževanja delavcev v Veliki Britaniji, je doumel, da to ni pomenilo nič manj kot kulturno revolucijo v načinu, kako vrednotimo izobraževanje in usposobljenost ljudi za učenje.

Namesto procesa, ki bi razvrščal in ocenjeval, kar je samoumevno za razredno družbo, bi morali imeti človekovo učenje za resnično odprto pot, za neprecenljivo bogastvo, za nekaj, o čemer bi morali načeti posebno razpravo o omejitvi, in ne o širitvi. Do tega se bomo morda dokopali šele takrat, ko se bomo naučili razmišljati o resnično odprti kulturi (Williams, 1961).

To, kar je Williams imenoval »dolga revolucija za ustvaritev povezav med učenjem ter zaslužkom in življenjem $\mathrm{v}$ demokratični ter resnično angažirani družbi, se nadaljuje. Mi pa moramo razširiti diskurz o državljanstvu, ki je zajet $\mathrm{v}$ političnem programu, $\mathrm{z}$ vseživljenjskim učenjem, predvsem zato, da bi postal integralni del te nedokončane revolucije. 